\title{
Clinical and genetic profile of catecholaminergic polymorphic ventricular tachycardia in Hong Kong Chinese children
}

\author{
TC Yu *, Anthony PY Liu, KS Lun, Brian HY Chung, TC Yung
}

\section{A B S T R A C T}

Objective: To report our experience in the management of catecholaminergic polymorphic ventricular tachycardia in Hong Kong Chinese children.

Methods: This case series study was conducted in a tertiary paediatric cardiology centre in Hong Kong. All paediatric patients diagnosed at our centre with catecholaminergic polymorphic ventricular tachycardia from January 2008 to October 2014 were included.

Results: Ten patients (five females and five males) were identified. The mean age at presentation and at diagnosis were 11.0 (standard deviation, 2.9) years and 12.5 (2.8) years, respectively. The mean delay time from first presentation to diagnosis was 1.5 (standard deviation, 1.3) years. They presented with recurrent syncope and six patients had a history of aborted cardiac arrest. Four patients were initially misdiagnosed to have epilepsy. Catecholaminergic polymorphic ventricular tachycardia was diagnosed by electrocardiogram at cardiac arrest $(n=2)$, or provocation test, either by catecholamine infusion test $(n=6)$ or exercise test $(n=2)$. Mutations of the
This article was published on 3 Jun 2016 at www.hkmj.org. $R y R 2$ gene were confirmed in six patients. Nine patients were commenced on beta-blockers after developed aborted or resuscitated cardiac arrest $(n=2)$ and syncope $(n=1)$. Left cardiac sympathetic denervation was performed in five patients and an implantable cardioverter defibrillator was implanted in another. There was no mortality during follow-up.

Conclusions: Catecholaminergic polymorphic ventricular tachycardia should be considered in children who present with recurrent syncope during exercise or emotional stress. Despite beta-blocker treatment, recurrent ventricular arrhythmias occur and may result in cardiac arrest.
Hong Kong Med J 2016;22:314-9 DOI: $10.12809 / \mathrm{hkmj} 154653$
${ }^{1} \mathrm{TC} Y \mathrm{Yu}^{*}, \mathrm{MB}, \mathrm{ChB}$, FHKAM (Paediatrics)
APY Liu, MB, BS, MRCPCH
${ }^{3}$ KS Lun, MB, ChB, FHKAM (Paediatrics)
2 BHY Chung, MB, ChB, FHKAM (Paediatrics)
${ }^{3}$ TC Yung, MB, BS, FHKAM (Paediatrics)

\section{Department of Paediatrics and Adolescent Medicine, Pamela Youde Nethersole Eastern Hospital, Chai Wan, Hong Kong of Medicine, The University of Hong Kong, Pokfulam, Hong Kong \\ ${ }^{3}$ Department of Paediatric Cardiology, Queen Mary Hospital, Pokfulam, Hong Kong}
${ }^{2}$ Department of Paediatrics and Adolescent Medicine, Li Ka Shing Faculty

* Corresponding author: ytc604@ha.org.hk

New knowledge added by this study

- This is the first study of catecholaminergic polymorphic ventricular tachycardia (CPVT) in Hong Kong describing local experience in the management of this rare arrhythmic syndrome.

- The genetic background ( $R y R 2$ mutation) of our Chinese children is similar to those in overseas studies. Implications for clinical practice or policy

- CPVT should be considered in young patients who present with exercise-related syncope.

- Maintaining a high index of suspicion and correct diagnosis of CPVT may be life-saving.

\section{Introduction}

Catecholaminergic polymorphic ventricular tachycardia (CPVT) is an inherited arrhythmia syndrome. Mutation of the ryanodine receptor $2(R y R 2)$ gene and infrequently the calsequestrin (CASQ2) gene is identified in approximately $60 \%$ to $70 \%$ of patients. ${ }^{1,2}$ Patients with CPVT usually present with syncope and sudden cardiac death. The symptoms are due to bidirectional polymorphic ventricular tachycardia (VT) induced by adrenergic stress. ${ }^{1}$ Onset of arrhythmia syndrome is usually in childhood. Many affected children are considered to have vasovagal syncope or epilepsy before a correct diagnosis is made. ${ }^{1-4}$ If left untreated, the mortality of CPVT is up to $31 \%$ by the age of 30 years. ${ }^{1,3,5}$

In this study, we reviewed the clinical characteristics, genetic profile, and outcome of CPVT in Hong Kong Chinese children.

\section{Methods}

Our study included children diagnosed with CPVT from January 2008 to October 2014 at Queen Mary 
Hospital, a university-affiliated teaching hospital in Hong Kong. The hospital records were retrospectively reviewed. Demographic data, clinical presentation, diagnostic methods, and genetic tests were reviewed. In all patients, the heart rate-corrected QT interval of the resting electrocardiogram was normal and the presence of structural heart disease was excluded by echocardiography $(n=10)$ and/or magnetic resonance imaging $(n=5)$. We also summarised the treatment modalities, response to treatment, and clinical outcome up to October 2014.

\section{Genetic analysis}

Blood samples of seven patients were sent to the Molecular Genetics Laboratory of Victorian Clinical Genetic Services, Australia where testing for mutations of the $R y R 2$ gene was performed. The assay involved sequencing of 17 hotspot exons (exons $1,8,14,15,44,46,47,49,88,93,95,97,101,102$, $103,104,105)$, their splice junctions and 20 bps into the introns. Since 2014, the Laboratory has made use of a cardiac next-generation sequencing panel to analyse the 28 arrhythmia genes: $A K A P 9, A N K 2$, CACNA1C, CACNA2D1, CACNB2, CASQ2, CAV3, GJA5, GPD1L, HCN4, KCNA5, KCND3, KCNE1, KCNE1L, KCNE2, KCNE3, KCNH2, KCNJ2, KCNJ5, KCNJ8, KCNQ1, NPPA, RYR2, SCN1B, SCN3B, $S C N 4 B, S C N 5 A$, and $S N T A 1$. In two patients, the samples were tested by the local Laboratory Genetic Service (Department of Pathology, Princess Margaret Hospital, Hong Kong), where direct sequencing of selected hotspot exons and the flanking introns (10 bps) was performed. Cascade testing was offered for first-degree relatives of genotype-positive subjects.

\section{香港華籍兒童中兒茶酚胺多形性心室心動過速的 臨床和基因譜}

\author{
余德政、廖栢賢、倫建成、鍾㑆言、翁德璋
}

目的：報告我們治理兒茶酚胺多形性心室心動過速（CPVT）香港華 籍兒童患者的經驗。

方法: 本病例系列研究在香港一所三級兒科心臟病學中心內進行。研 究對象包括2008年1月至2014年10月期間在上述中心確診CPVT的所 有兒童。

結果：共有10名CPVT患者（5男5女），他們病發及確診的平均年齡 分別為 11.0 歲 (標準差2.9歲) 和12.5 (2.8) 歲。病發至診迦的延誤 期為 1.5 年（標準差 1.3 年）。所有患者出現反覆暈厥, 其中 6 例曾出 現心藏驟停的現象。4例最初被誤診為癲癇。有 2 例在心藏驟停期間作 心電圖時才發現CPVT的症狀；其餘則在激發試驗當中因兒茶酚胺輸 液測試（6例）或運動（2例）而確診。患者中6例證實有 $R y R 2$ 基因突 變。9例患者確診後開始接受 $\beta$ 受體阻滯劑的治療。儘管接受了藥物治 療, 3 例仍出現中止或心臟驟停復更生 (2例) 和量厥（1例）。5例接受 左心交感神經切除術, 另 1 例接受植入式心臟復律除顫器。隨訪期間 並無死亡病例。

結論：當有兒童在運動期間或情緒緊張時反覆出現暈厥, 便應考慮 CPVT的可能性。儘管接受 $\beta$ 受體阻滯劑的治療, 復發性室性心律失常 仍會發生, 並可能導致心臟停頓。

TABLE I. Demographic data, clinical presentation, diagnostic method, and the threshold heart rate of polymorphic ventricular ectopic and ventricular tachycardia of the 10 patients

\begin{tabular}{|c|c|c|c|c|c|c|c|c|c|c|}
\hline $\begin{array}{l}\text { Patient } \\
\text { No. }\end{array}$ & Sex & $\begin{array}{c}\text { Age of } \\
\text { onset } \\
\text { (years) }\end{array}$ & $\begin{array}{c}\text { Age at } \\
\text { diagnosis } \\
\text { (years) }\end{array}$ & $\begin{array}{c}\text { Delay of } \\
\text { diagnosis } \\
\text { (years) }\end{array}$ & $\begin{array}{l}\text { Follow- } \\
\text { up } \\
\text { duration } \\
\text { (years) }\end{array}$ & Presentation & Diagnostic method & $\begin{array}{c}\text { QTc } \\
\text { interval } \\
\text { of resting } \\
\text { ECG }(\mathbf{m s})\end{array}$ & $\begin{array}{c}\text { VE } \\
\text { threshold } \\
\text { (heart rate, } \\
\text { beats/min) }\end{array}$ & $\begin{array}{c}\text { VT } \\
\text { threshold } \\
\text { (heart rate, } \\
\text { beats } / \mathrm{min} \text { ) }\end{array}$ \\
\hline 1 & Male & 6.2 & 6.9 & 0.7 & 6.7 & Syncope & Isoprenaline infusion & 426 & 120 & 140 \\
\hline 2 & Female & 11.0 & 14.1 & 3.1 & 5.5 & Syncope & Adrenaline infusion & 394 & 110 & 142 \\
\hline 3 & Female & 9.7 & 13.0 & 3.3 & 6.4 & Syncope & Treadmill & 416 & 150 & 150 \\
\hline 4 & Female & 14.2 & 14.3 & 0.1 & 4.7 & Aborted cardiac arrest & Arrest ECG & 422 & 90 & 126 \\
\hline $5^{*}$ & Male & 11.6 & 14.9 & 3.4 & 2.9 & Syncope & Treadmill & 406 & 125 & NA \\
\hline 6 & Female & 7.2 & 9.2 & 2.0 & 2.7 & Aborted cardiac arrest & Adrenaline infusion & 396 & 110 & 166 \\
\hline 7 & Female & 13.7 & 15.1 & 1.4 & 2.7 & Syncope & Adrenaline infusion & 444 & 126 & 170 \\
\hline 8 & Male & 13.2 & 13.2 & 0 & 2.4 & Aborted cardiac arrest & Adrenaline infusion & 380 & 117 & 138 \\
\hline $9^{*}$ & Male & 14.0 & 14.4 & 0.3 & 2.0 & Aborted cardiac arrest & Arrest ECG & 423 & NA & NA \\
\hline 10 & Male & 9.3 & 10.0 & 0.7 & 0.7 & Syncope & Adrenaline infusion & 404 & 120 & 130 \\
\hline
\end{tabular}

Abbreviations: $\mathrm{ECG}=$ electrocardiogram; NA = not available; $\mathrm{QTc}=$ heart rate-corrected $\mathrm{QT}$; VE = ventricular ectopic; $\mathrm{VT}=$ ventricular tachycardia

* Brothers of the same family 

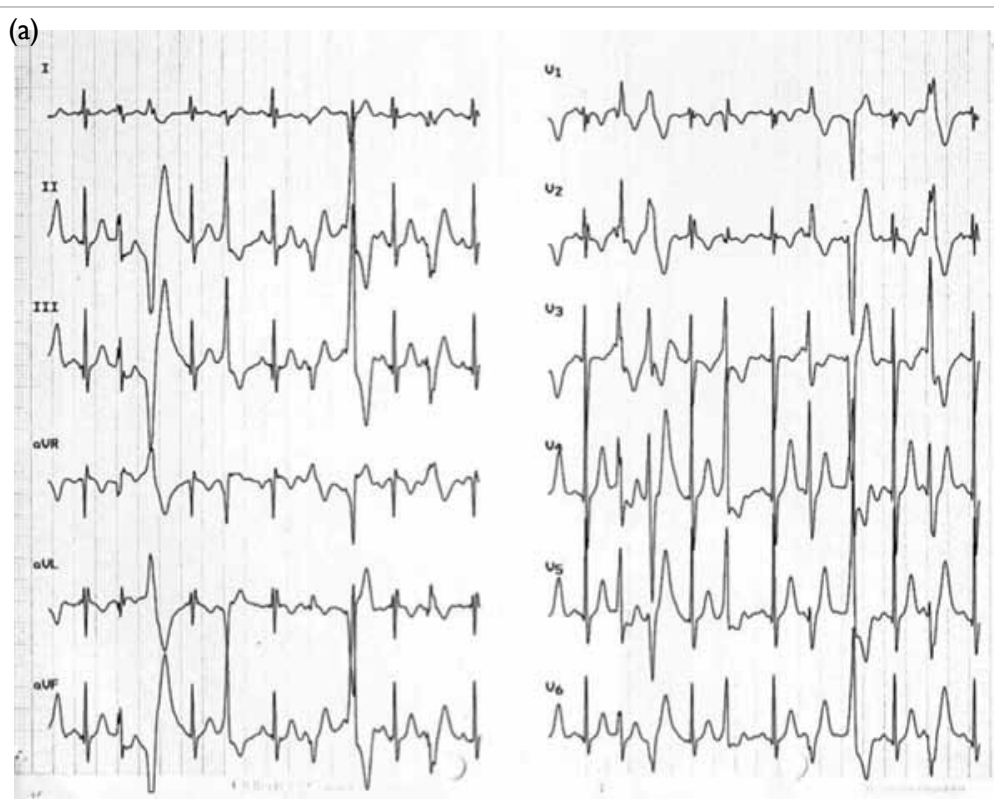

(b)

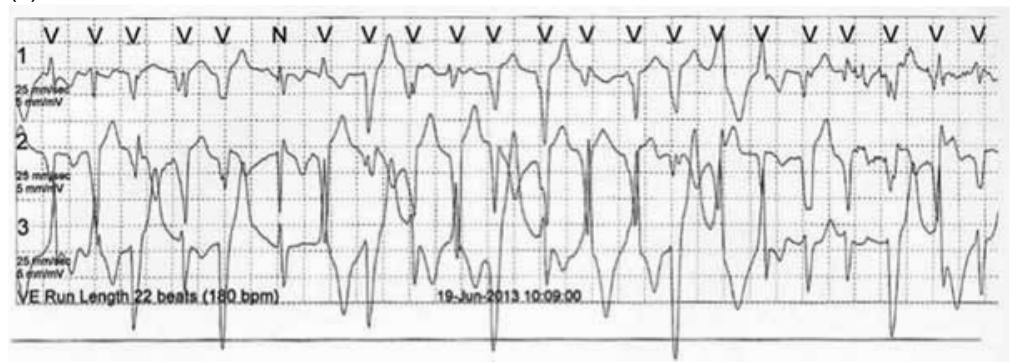

FIG. Patient I: (a) polymorphic ventricular ectopics, with bidirectional QRS complexes induced by exercise test; and (b) polymorphic ventricular tachycardia, with bidirectional QRS complexes recorded by Holter monitoring features are summarised in Table 1. The group comprised five female and five male patients; two of whom were brothers. The mean ( \pm standard deviation) age at first presentation was $11.0 \pm 2.9$ (range, 6.2-14.2) years. The mean age at diagnosis was $12.5 \pm 2.8$ (range, 6.9-15.1) years. The mean delay time from first presentation to diagnosis was $1.5 \pm 1.3$ years.

Six patients presented initially with syncope while the other four presented with aborted cardiac arrest. At the end of the study, a total of six patients had aborted cardiac arrest. The triggering event for syncope or cardiac arrest was either exercise or emotion. Nonetheless, no such event was evident in three patients.

Four patients were initially misdiagnosed with epilepsy, one of whom was treated with an anticonvulsant prior to the diagnosis of CPVT.

Of the four patients who presented with aborted cardiac arrest, three required repeated cardioversion because of recurrent VT immediately following successful termination of ventricular arrhythmias. The case of patient 4 has been reported previously. ${ }^{6}$

\section{Diagnosis of catecholaminergic polymorphic ventricular tachycardia and genetic analysis}

Diagnosis of CPVT in two patients was based on the presence of bidirectional polymorphic VT in the cardiac arrest electrocardiogram. In the remaining patients, diagnosis was made when polymorphic or bidirectional VT was induced during provocation tests by exercise $(n=2)$ or catecholamine infusion $(n=6)$. Heart rate at the induction of ventricular premature beats ranged from 90 to 150 beats/min. Polymorphic VTs were induced when heart rate was increased to 126 to 170 beats/min (Fig).

Of the nine patients with genetic study, six were confirmed to have mutations of the $R y R 2$ gene as shown in Table 2. One patient (patient 9) did not undergo genetic study because his brother (patient 5 ) was confirmed to have no mutation of $R y R 2$. Only two (brothers of the same family) of 10 patients had a family history of cardiac arrhythmic events. There was no $R y R 2$ mutation identified in the first-degree relatives of any patient with a $R y R 2$ mutation.

\section{Treatment and response}

\section{Medical treatment}

The treatment modalities and response are summarised in Table 3. All patients were started on a beta-blocker as first-line medication. One patient initially refused medical treatment. She then had recurrent syncope and subsequently agreed to treatment with nadolol.

Metoprolol was prescribed to three patients as initial medical treatment, although all switched to nadolol with or without flecainide due to unsatisfactory control (aborted cardiac arrest in one and exercise-induced polymorphic VT in another) or intolerable side-effects (tiredness and significant bradycardia at 38 beats $/ \mathrm{min}$ ).

Of the six patients prescribed nadolol as the first medication, five had no more syncope and no VT on treadmill exercise testing. Nadolol was changed to flecainide in one patient (patient 7) due to significant resting bradycardia of 35 beats $/ \mathrm{min}$. Nadolol was later resumed at a lower dose.

Atenolol was started in one girl as initial medical treatment but failed to prevent recurrent syncope. After changing to nadolol, she remained symptomatic and subsequently underwent left cardiac sympathetic denervation (LCSD).

\section{Additional treatments}

Left cardiac sympathetic denervation was performed via a video-assisted thoracoscopic approach in five 
TABLE 2. RyR2 mutations identified in our cohort

\begin{tabular}{|c|c|c|c|c|}
\hline $\begin{array}{l}\text { Patient } \\
\text { No. }\end{array}$ & Detection method & $\begin{array}{l}\text { Nucleotide } \\
\text { change }\end{array}$ & Mutation & Novel \\
\hline 1 & Sequencing of selected hotspot (exon 105) & $14848 \mathrm{G}>\mathrm{A}$ & E4950K & No \\
\hline 2 & NGS - arrhythmia panel & $12475 C>A$ & Q4159K & Yes \\
\hline 3 & Sequencing of 17 hotspots & Negative & Negative & Not applicable \\
\hline 4 & Sequencing of 17 hotspots & $7420 A>G$ & $\mathrm{R} 2474 \mathrm{G}$ & Yes \\
\hline 5 & Sequencing of 17 hotspots & Negative & Negative & Not applicable \\
\hline 6 & $\begin{array}{l}\text { Sequencing of selected hotspots (exons } 3,8,14,46,47,49,88,89,90,93,97,100 \text {, } \\
101,103)^{\star}\end{array}$ & $11836 \mathrm{G}>\mathrm{A}$ & G3946S & No \\
\hline 7 & Sequencing of 17 hotspots & Negative & Negative & Not applicable \\
\hline 8 & Sequencing of 17 hotspots & $14861 C>G$ & A4954G & Yes \\
\hline 9 & Not tested (as sibling tested negative) & - & - & - \\
\hline 10 & NGS - arrhythmia panel & $12475 C>A$ & Q4159K & Yes \\
\hline
\end{tabular}

Abbreviation: NGS = next-generation sequencing

* Test performed in local Laboratory Genetic Service

TABLE 3. The medical and surgical treatment, most-severe arrhythmic events during follow-up, and the latest Holter or Treadmill results with current treatment of the 10 patients

\begin{tabular}{|c|c|c|c|c|c|c|}
\hline $\begin{array}{l}\text { Pa- } \\
\text { tient } \\
\text { No. }\end{array}$ & $\begin{array}{c}\text { RyR2 } \\
\text { mutation }\end{array}$ & $\begin{array}{l}\text { Initial medical } \\
\text { treatment }\end{array}$ & Current treatment & $\begin{array}{l}\text { Most-severe } \\
\text { arrhythmic } \\
\text { event during } \\
\text { follow-up }\end{array}$ & $\begin{array}{l}\text { Resting heart } \\
\text { rate at last } \\
\text { follow-up } \\
\text { (beats/min) }\end{array}$ & $\begin{array}{l}\text { Latest Holter / Treadmill results with } \\
\text { current treatment }\end{array}$ \\
\hline 1 & Positive & Metoprolol 25 mg BD & $\begin{array}{l}\text { Nadolol } 60 \text { mg daily + } \\
\text { flecainide } 50 \text { mg BD + LCSD }\end{array}$ & $\begin{array}{c}\text { Aborted } \\
\text { cardiac arrest }\end{array}$ & 39 & $\begin{array}{l}\text { Holter: still polymorphic VT at } 182 / \mathrm{min} \\
\text { Treadmill: no exercise-induced } \\
\text { tachyarrhythmia }\end{array}$ \\
\hline 2 & Positive & Metoprolol 50 mg BD & $\begin{array}{l}\text { Flecainide } 100 \text { mg/150 mg BD } \\
\text { + LCSD }\end{array}$ & Nil & 37 & $\begin{array}{l}\text { Holter: no VE or VT } \\
\text { Treadmill: polymorphic VE (triplets), less } \\
\text { sustained }\end{array}$ \\
\hline 3 & Negative & Refused & Nadolol 40 mg daily & Syncope & 53 & $\begin{array}{l}\text { Treadmill: much less polymorphic VEs, } \\
\text { no VT }\end{array}$ \\
\hline 4 & Positive & Atenolol 50 mg daily & Nadolol 40 mg daily + LCSD & Syncope & 46 & $\begin{array}{l}\text { Treadmill (after LCSD): less frequent } \\
\text { exercise-induced VEs; no VT }\end{array}$ \\
\hline 5 & Negative & Nadolol 60 mg daily & Nadolol 60 mg daily & Nil & 52 & $\begin{array}{l}\text { Holter: no VE or VT } \\
\text { Treadmill: frequent monomorphic VE } \\
\text { but no VT induced }\end{array}$ \\
\hline 6 & Positive & Nadolol 60 mg daily & Nadolol 80 mg daily + LCSD & Nil & 53 & $\begin{array}{l}\text { Holter and Treadmill with current } \\
\text { treatment not performed yet at the end } \\
\text { of study }\end{array}$ \\
\hline 7 & Negative & Nadolol 10 mg daily & $\begin{array}{l}\text { Nadolol } 20 \text { mg daily + } \\
\text { flecainide } 150 \text { mg BD + ICD }\end{array}$ & $\begin{array}{c}\text { Aborted } \\
\text { cardiac arrest }\end{array}$ & 59 & $\begin{array}{l}\text { Holter: no VE } \\
\text { Treadmill: no exercise-induced VE }\end{array}$ \\
\hline 8 & Positive & $\begin{array}{l}\text { Metoprolol 50/75 mg } \\
\text { BD }\end{array}$ & $\begin{array}{l}\text { Nadolol } 100 \text { mg daily + } \\
\text { flecainide } 100 \text { mg BD + LSCD }\end{array}$ & Nil & 47 & Treadmill: no VE or VT \\
\hline 9 & Refused & Nadolol 80 mg daily & Nadolol 80 mg daily & Nil & 62 & Treadmill: no exercise-induced VE or VT \\
\hline 10 & Positive & Nadolol 20 mg daily & Nadolol 80 mg daily & Nil & 60 & $\begin{array}{l}\text { Treadmill: short runs of polymorphic VT } \\
\text { ( } 5 \text { beats) }\end{array}$ \\
\hline
\end{tabular}

Abbreviations: BD = twice daily; ICD = implantable cardioverter defibrillator; $L C S D=$ left cardiac sympathetic denervation; VE = ventricular ectopic; $V T=$ ventricular tachycardia

patients. The lower half of the stellate ganglion and defibrillator (ICD) implantation was performed the sympathetic trunk of T2 to T4 were resected. in one patient (patient 7) who experienced an After LCSD, one patient (patient 1) still had recurrent aborted cardiac arrest despite flecainide. She had syncope. The other four patients had no more no complications related to the ICD implantation. syncope. Dual-chamber implantable cardioverter After implantation, she had one episode of syncope 
while she was swimming slowly in the pool with her mother. She was taken out of the water and was able to stand unaided soon after. The ICD interrogation noted an episode of VT/ventricular fibrillation that was successfully aborted by electric shocks from the ICD. She had no inappropriate shocks from the ICD during the follow-up period of 30 months.

\section{Outcomes}

The median duration of follow-up was $3.7 \pm 2.0$ (range, 0.7-6.7) years. Six (60\%) patients became asymptomatic after drug treatment. Two patients had recurrent syncope; one of whom was without drug treatment. Two patients experienced aborted cardiac arrest, one received ICD implantation and another one refused. There was no mortality during the study period.

\section{Discussion}

Catecholaminergic polymorphic ventricular tachycardia is uncommon in Hong Kong Chinese children. Our centre treated most of the serious local paediatric cardiac arrhythmia cases. Over a period of 7 years we identified only 10 patients. Our case series is, to date, the largest in Chinese children.

Many of our patients (6 out of 10) had experienced aborted cardiac arrest as the nearfatal arrhythmic event during the study. The diagnosis of CPVT can be challenging and requires documentation of typical bidirectional polymorphic $\mathrm{VT}$ at presentation, or induction of polymorphic VT by exercise test or catecholamine infusion test. ${ }^{1-3,7,8}$ Studies show that diagnosis of CPVT can be made in $69 \%$ and $75 \%$ of patients by exercise test and catecholamine infusion test, respectively., ${ }^{9,10}$

Misdiagnosis and delay in diagnosis of CPVT is common. Our patients had a mean delay of 1.5 years from first presentation to diagnosis. Four of our patients were initially misdiagnosed with epilepsy, one of whom was prescribed anticonvulsant therapy. Of the 10 patients, four were not diagnosed until they presented with aborted cardiac arrest.

Genetic mutations are identified in $60 \%$ to $70 \%$ of patients with CPVT, and more than $90 \%$ of the mutations affect the RyR2 gene..$^{1,3}$ Mutation of the CASQ2 gene is rare $(<2 \%)$. Very recently, mutation of triadin, a transmembrane sarcoplasmic reticulum protein, was found to be the cause of CPVT in two families. ${ }^{11}$ In these mutations, the defective proteins cause excessive calcium release from the sarcoplasmic reticulum to the cytoplasm leading to polymorphic VT. ${ }^{1,5}$ Similar to overseas studies, mutation of the $R y R 2$ gene was evident in the majority $(60 \%)$ of our patients.

Patients with CPVT must be restricted from exercise to avoid the adrenergic trigger. A betablocker serves as first-line medical therapy. ${ }^{1,2,4,10}$
Nonetheless, CPVT is a very malignant arrhythmic disease and many patients remain symptomatic despite such therapy. ${ }^{1,3,4,10}$ In a systematic analysis of 354 CPVT patients treated with beta-blockers, the estimated 8-year arrhythmic event rate was $37.2 \% .^{12}$ Our study also showed that a high proportion of patients still developed arrhythmic events despite beta-blocker treatment (syncope in one and aborted cardiac arrest in two out of 10 patients).

In the early period of study, we prescribed metoprolol in three patients, although all experienced treatment failure due to recurrent symptoms or intolerance. In the later period, nadolol was the initial medication and five out of six patients became asymptomatic.

Flecainide, a class $1 \mathrm{c}$ anti-arrhythmic drug with dual action of direct ryanodine receptor blockage and blockage of sodium channels, ${ }^{1,12}$ may be effective in CPVT patients. Flecainide has been evaluated in a multicentre study of 33 CPVT patients. In 22 (76\%) out of 29 patients, flecainide suppressed exerciseinduced ventricular arrhythmia either partially $(n=8)$ or completely $(\mathrm{n}=14)^{1,12,13}$ In our study, flecainide was used in four patients who had failed treatment with a beta-blocker. Three patients still had arrhythmic events, however.

Studies showed that LCSD, which prevents noradrenaline release in the heart, is highly effective in severely affected CPVT patients. ${ }^{14,15}$ It can be performed with a minimally invasive approach by video-assisted thoracic surgery. In our study, five patients underwent LCSD. All recovered well and no complications were noted at follow-up. Four had no more syncope. Large studies are needed to further evaluate its efficacy in CPVT patients.

An ICD has been recommended in patients who fail optimised medical therapy. ${ }^{1,12,14,16}$ Some recent studies have suggested that ICD may be harmful to CPVT patients, however, because both appropriate and inappropriate ICD shocks can potentially induce VT storms and cardiac arrest. ${ }^{16,17}$ Therefore, ICD implantation should be restricted to patients with symptoms refractory to optimised medical treatment and LCSD. ${ }^{18}$

\section{Conclusions}

Catecholaminergic polymorphic ventricular tachycardia is an uncommon but malignant cardiac arrhythmia that presents as syncope, seizure, or sudden cardiac death in childhood. In our study, $60 \%$ of patients experienced aborted cardiac arrest. One should suspect the diagnosis when syncope occurs during exercise or emotional stress. Similar to overseas studies, RyR2 mutation is the most common genetic mutation and affected $60 \%$ of our patients. Despite optimised medical therapy, $60 \%$ of patients still required LCSD or ICD implantation. 


\section{Acknowledgements}

The expenses of genetic analysis were sponsored by the Children's Heart Foundation of Hong Kong.

\section{Declaration}

All authors have no relevant conflicts of interest to disclose.

\section{References}

1. Ylänen K, Poutanen T, Hiippala A, Swan H, Korppi M. Catecholaminergic polymorphic ventricular tachycardia. Eur J Pediatr 2010;169:535-42.

2. Priori SG, Napolitano C, Memmi M, et al. Clinical and molecular characterization of patients with catecholaminergic polymorphic ventricular tachycardia. Circulation 2002;106:69-74.

3. Leenhardt A, Lucet V, Denjoy I, Grau F, Ngoc DD, Coumel P. Catecholaminergic polymorphic ventricular tachycardia in children. A 7-year follow-up of 21 patients. Circulation 1995;91:1512-9.

4. Çeliker A, Erdoğan I, Karagöz T, Özer S. Clinical experiences of patients with catecholaminergic polymorphic ventricular tachycardia. Cardiol Young 2009;19:45-52.

5. Swan H, Piippo K, Viitasalo M, et al. Arrhythmic disorder mapped to chromosome 1q42-q43 causes malignant polymorphic ventricular tachycardia in structurally normal hearts. J Am Coll Cardiol 1999;34:2035-42.

6. Kung SW, Yung TC, Chiu WK. Successful resuscitation of out-of-hospital ventricular fibrillation cardiac arrest in an adolescent. Hong Kong J Emerg Med 2010;17:482-7.

7. Lahat H, Eldar M, Levy-Nissenbaum E, et al. Autosomal recessive catecholamine- or exercise-induced polymorphic ventricular tachycardia: clinical features and assignment of the disease gene to chromosome 1p13-21. Circulation 2001;103:2822-7.

8. Postma AV, Denjoy I, Kamblock J, et al. Catecholaminergic polymorphic ventricular tachycardia: RYR2 mutations, bradycardia, and follow up of the patients. J Med Genet 2005;42:863-70.
9. Marjamaa A, Hiippala A, Arrhenius B, et al. Intravenous epinephrine infusion test in diagnosis of catecholaminergic polymorphic ventricular tachycardia. J Cardiovasc Electrophysiol 2012;23:194-9.

10. Sumitomo N, Harada $K$, Nagashima $M$, et al. Catecholaminergic polymorphic ventricular tachycardia: electrocardiographic characteristics and optimal therapeutic strategies to prevent sudden death. Heart 2003;89:66-70.

11. Roux-Buisson N, Cacheux M, Fourest-Lieuvin A, et al. Absence of triadin, a protein of the calcium release complex, is responsible for cardiac arrhythmia with sudden death in human. Hum Mol Genet 2012;21:2759-67.

12. van der Werf C, Zwinderman AH, Wilde AA. Therapeutic approach for patients with catecholaminergic polymorphic ventricular tachycardia: state of the art and future developments. Europace 2012;14:175-83.

13. van der Werf C, Kannankeril PJ, Sacher F, et al. Flecainide therapy reduces exercise-induced ventricular arrhythmias in patients with catecholaminergic polymorphic ventricular tachycardia. J Am Coll Cardiol 2011;57:2244-54.

14. Wilde AA, Bhuiyan ZA, Crotti L, et al. Left cardiac sympathetic denervation for catecholaminergic polymorphic ventricular tachycardia. N Engl J Med 2008;358:2024-9.

15. De Ferrari GM, Dusi V, Spazzolini C, et al. Clinical management of catecholaminergic polymorphic ventricular tachycardia: the role of left cardiac sympathetic denervation. Circulation 2015;131:2185-93.

16. Miyake CY, Webster G, Czosek RJ, et al. Efficacy of implantable cardioverter defibrillators in young patients with catecholaminergic polymorphic ventricular tachycardia: success depends on substrate. Circ Arrhythm Electrophysiol 2013;6:579-87.

17. Mohamed U, Gollob MH, Gow RM, Krahn AD. Sudden cardiac death despite an implantable cardioverterdefibrillator in a young female with catecholaminergic ventricular tachycardia. Heart Rhythm 2006;3:1486-9.

18. van der WerfC, Wilde AA. Catecholaminergic polymorphic ventricular tachycardia: from bench to bedside. Heart 2013;99:497-504. 